\title{
PENGARUH PERTUMBUHAN EKONOMI DAN UPAH MINIMUN TERHADAP PENDAPATAN PERKAPITA DI KABUPATEN LUWU TIMUR
}

\author{
Andi Rizkiyah Hasbi1 ${ }^{*}$, A. Dahri AP1, Salju ${ }^{1}$ \\ ${ }^{1}$ Sekolah Tinggi Ilmu Ekonomi Muhammadiyah \\ *andirizkiyahhasbi@gmail.com
}

\begin{abstract}
The coefficient of economic growth for the X1 variable is 44579,598. This means that every increase in Economic Growth is equal to one unit, the income per capita or variable $Y$ will increase by 44597,598 assuming that the other independent variables of the regression model are fixed. The minimum wage for variable X2 against beta (Y), the Minimum Wage coefficient value for variable X2 is 2,621. This means that every increase in wages has a minimum of one unit so that the $Y$ variable will increase by 2,621 assuming that the other independent variables of the regression model are fixed. The purpose of this study is to find out whether Economic Growth and Minimum Wages affect Per capita Income in East Luwu District.
\end{abstract}

Keywords: Economy, Minimum Wage, Percapita Income

\begin{abstract}
Abstrak
Nilai koefisien pertumbuhan ekonomi untuk variable X1 sebesar 44579,598. Hal ini mengandung arti bahwa setiap kenaikan Pertumbuhan Ekonomi sebesar satu satuan maka pendapatan perkapita atau variable Y akan naik sebesar 44597,598 dengan asumsi bahwa variable bebas yang lain dari model regresi adalah tetap. Upah minimum untuk variable X2 terhadap beta (Y), nilai koefisien Upah Minimum untuk variable X2 sebesar 2,621. Hal ini mengandung arti bahwa setiap kenaikan Upah minimum satu satuan maka variable Y akan naik sebesar 2,621 dengan asumsi bahwa variable bebas yang lain dari model regresi adalah tetap. Tujuan dari penelitian ini adalah untuk mengetahui apakah Pertumbuhan Ekonomi dan Upah Minimum berprngaruh terhadap Pendapatan Perkapita di Kabupaten Luwu Timur.
\end{abstract}

Kata Kunci : Pertumbuhan Ekonomi, Upah Minimum, Pendapatan Perkapita

\section{PENDAHULUAN}

Kabupaten Luwu Timur adalah salah satu Daerah Tingkat II di provinsi Sulawesi Selatan, Indonesia. Kabupaten ini berasal dari pemekaran Kabupaten Luwu Utara yang disahkan dengan UU Nomor 7 Tahun 2003 pada tanggal 25 Februari 2003. Malili adalah ibu kota dari Kabupaten Luwu Timur yang terletak di ujung utara Teluk Bone. Kabupaten ini memiliki luas wilayah $6.944,98 \mathrm{~km}^{2}$. Kabupaten ini terdiri atas 11 Kecamatan yakni Kecamatan Malili, kecamatan Angkona, Tomoni, Tomoni Timur, Kalaena, Towuti, Nuha, Wasponda, Wotu, Burau dan Mangkutana. Di kabupaten ini terletak Sorowako, tambang nikel yang dikelola oleh INCO, sebuah perusahaan Kanada yang kini berubah nama menjadi PT Vale. Pendapatan per kapita masyarakat Luwu Timur pada tahun 2014 adalah Rp. 75,58 juta.

Kabupaten Luwu Timur memiliki 5 danau dan 13 sungai. Hampir semua danau di
Luwu Timur berada di Kecamatan Towuti kecuali Danau Matano yang terletak di Kecamatan Nuha. Danau yang terdalam adalah Danau Matano yang mencapai kedalaman sekitar 589 meter. Sedangkan danau terluas adalah Danau Towuti yang memiliki luas sekitar $585 \mathrm{~km}^{2}$. Suangai terpanjang di Luwu Timur adalah Sungai Kalaena dengan panjang $85 \mathrm{~km}$, sedangkan sungai terpendek adalah Sungai Bambalu dengan panjang $15 \mathrm{~km}$.

Pendapatan perkapita adalah besarnya pendapatan rata-rata penduduk di suatu negara. Pendapatan perkapita didapatkan dari hasil pembagian pendapatan nasional suatu negara dengan jumlah penduduk negara tersebut. Pendapatan perkapita juga merefleksikan PDB perkapita. Pendapatan per kapita sering digunakan sebagai tolok ukur kemakmuran dan tingkat pembangunan sebuah negara; semakin besar pendapatan 
per kapitanya, semakin makmur negara tersebut.

\section{Gambar 1.1}

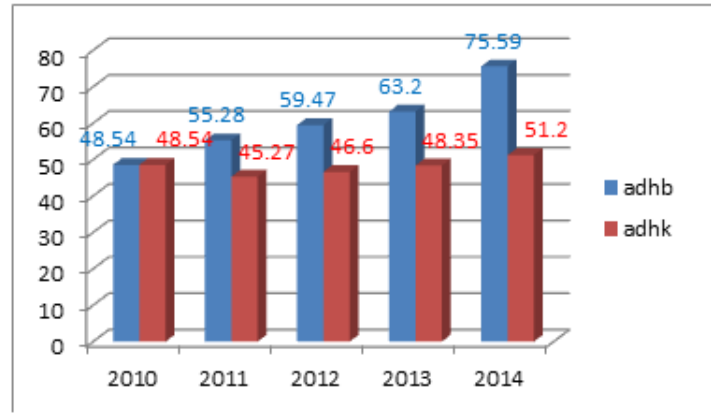

PDRB Perkapita Kab. Luwu Timur Tahun 2010-2014

Pendapatan perkapita Kabupaten Luwu Timur atas dasar harga berlaku (adhb) selama 5 tahun terakhir terus meningkat. Dari 48,53 juta rupiah pada tahun 2010 hingga mencapai 75,59 juta pada tahun 2014. Sementara itu berdasarkan atas dasar hanrga konstan, terjadi satu kali penurunan nilai pada tahun 2011 dan tidak terjadi lagi pada 3 tahun berikutnya.

Sementara itu, tren nilai PDRB atas dasar harga konstan (adhk) terlihat lebih fluktuatif dari nilai adhb. Pada tahun 2010, total nilai tambah bruto adhk di Luwu Timur mencapai 11,83 trilyun rupiah. Tahun berikutnya, total nilai tambah yang dihasilkan mengalami penurunan sekitar 507,6 miliar (4,29\%). Pada tahun 2012 kategori ekonomi kembali bangkit. Nilai tambah bruto adhk seluruh kategori usaha meningkat 5,6 \% dari tahun 2011, dan hal tersebut terus bertahan hingga tahun 2014. PDRB adhk tahun 2014 selisihnya 1,07 trilyun dari tahun sebelumnya naik $8,47 \%$.

Pertumbuhan ekonomi dan pendapatan perkapita merupakan indikator paling penting untuk melihat keberhasilan pembangunan suatu wilayah/ daerah. Setiap Negara akan berusaha keras untuk mencapai pertumbuhan ekonomi yang optimal. Di banyak Negara di dunia syarat utama bagi terciptanya penurunan kemiskinan adalah pertumbuhan ekonomi. Namun, kondisi di negara-negara berkembang termasuk Indonesia khususnya di Luwu Timur pertumbuhan ekonomi yang dicapai ternyata juga diiringi dengan munculnya permasalahan tingkat pendapatan perkapita yang ada di wilayah Kab. Luwu Timur. Untuk mewujudkan pemerataan pembangunan antar daerah yang nantinya dapat mengentaskan kondisi pendapatan perkapita.

Upah Minimum menjadi salah satu indikator bagi pendapatan perkapita. Upah minimum yang rendah berarti penduduk di suatu wilayah tersebut memiliki standar hidup dan tingkat konsumsi yang rendah pula, sedangkan kota atau kabupaten yang memiliki upah minimum yang tinggi berarti penduduk di kota atau kabupaten tersebut memiliki standar hidup dan tingkat konsumsi yang tinggi. Dan standar uapah minimum di Kabupaten Luwu Timur tahun 2010 sampai dengan 2014 dapat dilihat tingkat kenaikannnya dari tahun ketahun yang tergambar pada gambar grafik berikut:

Gambar 1.2

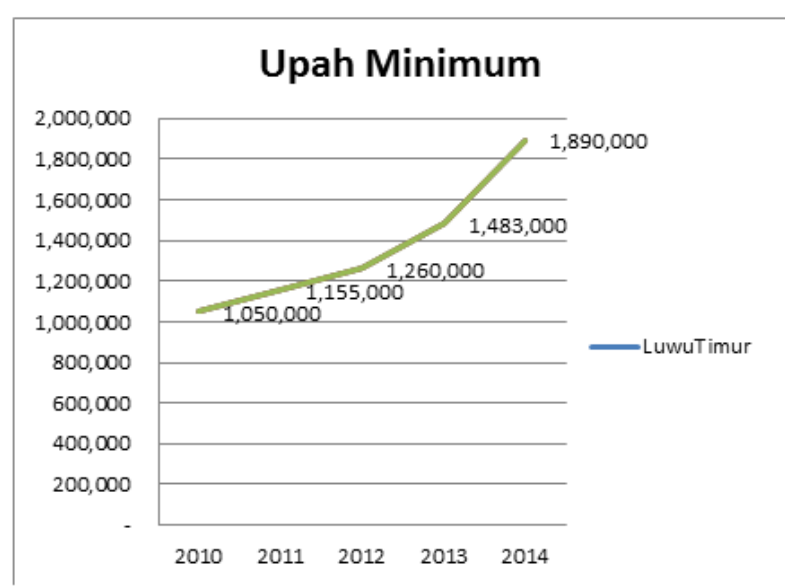

Dari grafik di atas tergambar dengan jelas bahwa dari tahun ke tahun upah minimum di Kabupaten Luwu Timur terus meningkat. Hal ini terjadi karena diharapkan dapat meningkatkan taraf hidup masyarakat.

\section{TINJAUAN PUSTAKA DAN PERUMUSAN HIPOTESIS}

Model Pertumbuhan menurut Mankiw (Principles of Macroeconomic edisi 3), faktor utama yang mempengaruhi perbedaan standard of living (ditunjukkan oleh 
perbedaan besar pendapatan per kapita) antara negara kaya dan negara miskin adalah tingkat produktivitas. Produktivitas mengacu pada jumlah barang dan jasa yang dapat dihasilkan oleh seorang pekerja dalam setiap jam. Dengan demikian, suatu negara dapat menikmati standard of living yang tinggi jika negara tersebut dapat memproduksi barang dan jasa dalam jumlah yang besar (Oktavia, 2008:2).

Ada beberapa faktor yang memengaruhi produktivitas suatu negara yang masing-masing dapat dianggap sebagai input produksi, yaitu physical capital, human capital, sumber daya alam, technological knowledge.

\section{Pengertian Pendapatan Perkapita}

Pendapatan perkapita adalah pendapatan rata-rata untuk masing-masing penduduk dalam suatu negara selama satu periode tertentu. Adapun rumusnya sebagai berikut.

Pendapatan Nasional

Pendapatan perkapkita

Jumlah Penduduk

Sumber: Sri Widiyati, (2011: 4).

Pendapatan perkapita ialah besarnya pendapatan rata-rata penduduk di suatu negara. Pendapatan perkapita didapatkan dari hasil pembagian pendapatan nasional suatu negara dengan jumlah penduduk negara tersebut. Pendapatan perkapita juga merefleksikan PDB perkapita. Pendapatan per kapita sering digunakan sebagai tolok ukur kemakmuran dan tingkat pembangunan sebuah negara; semakin besar pendapatan per kapitanya, semakin makmur negara tersebut.

Pendapatan perkapita ialah pendapatan rata-rata penduduk pada suatu Negara pada priode tertentu (umumnya satu tahun)
GDP tahun $x$

GDP per kapita $=$

Jumlah penduduk tahun $\mathrm{x}$

GNP tahun $x$

GNP per kapita $=$

Jumlah penduduk tahun $\mathrm{x}$

Ada dua cara untuk menghitung pendapatan perkapita, yaitu berdasarkan harga yang sedang berlaku dan berdasarkan harga tetap (konstan). Jika kita berhitung berdasarkan harga yang berlaku maka hasilnya disebut pendapatan perkapita nominal, sedangkan jika dihitung berdasarkan harga tetap (konstan) maka hasilnya disebut pendapatan perkapita riil.

\section{Faktor Yang Mempengaruhi Pendapatan Perkapita}

\section{Pertumbuhan Ekonomi}

Pertumbuhan ekonomi didefinisikan sebagai penjelasan mengenai faktor-faktor apa yang menentukan kenaikan output perkapita dalam jangka panjang, dan penjelasan mengenai bagaimana faktor-faktor tersebut berinteraksi satu sama lain, sehingga terjadi proses pertumbuhan. Jadi teori pertumbuhan ekonomi tidak lain adalah suatu kriteria (yang logis) mengenai bagaimana proses pertumbuhan terjadi. (Boediono, 1981:48). Menurut Todaro (2000:76), ada tiga faktor atau komponen utama dalam pertumbuhan ekonomi dari setiap bangsa. Ketiganya adalah akumulasi modal (capital accumulation) termasuk semua investasi baru yang berwujud tanah (lahan), peralatan fiskal, dan sumber daya manusia (human resources). terjadi apabila sebagian dari pendapatan ditabung dan diinvestasikan kembali dengan tujuan memperbesar output dan pendapatan 
di kemudian hari. Pengadaan pabrik baru, mesin-mesin, peralatan dan bahan baku meningkatkan stok modal (capital stock). Investasi harus dilengkapi dengan berbagai investasi penunjang yang disebut investasi infrastruktur ekonomi dan sosial. Contohnya adalah pembangunan jalan-jalan raya, penyediaan listrik, persediaan air bersih dan perbaikan sanitasi, pembangunan fasilitas komunikasi dan sebagainya, yang kesemuanya itu mutlak dibutuhkan dalam rangka menunjang dan mengintegrasikan segenap aktivitas ekonomi produktif.

Pertumbuhan penduduk dan angkatan kerja secara tradisional dianggap sebagai salah satu faktor positif yang memacu pertumbuhan ekonomi. Jumlah tenaga kerja yang lebih besarberarti akan menambah jumlah tenaga kerja produktif, sedangkan pertumbuhan penduduukyang lebih besar berarti ukuran pasar domestik nya lebih besar.

\section{a. Kemajuan Teknologi (technological} progress). Kemajuan teknologi terjadi karena ditemukannya cara baru atau perbaikan atas cara-cara lama dalam menangani pekerjaan tradisional.

Pertumbuhan ekonomi merupakan perubahan tingkat kegiatan ekonomi yang berlangsung dari tahun ke tahun. Untuk mengetahui tingkat pertumbuhan ekonomi harus membandingkan pendapatan nasional yang dihitung berdasarkan nilai riil. Jadi perubahan pendapatan nasional hanya semata-mata disebabkan oleh perubahan dalam tingkat kegiatan ekonomi atau dengan kata lain pertumbuhan baru tercapai apabila jumlah barang dan jasa yang dihasilkan bertambah besar pada tahun berikutnya. Untuk mengetahui apakah perekonomian mengalami pertumbuhan, harus dibedakan PDRB riil suatu tahun dengan PDRB riil tahun sebelumnya (Sukirno, 2004:19).

Menurut Kuznet (dalam Jhingan, 1994:72), pertumbuhan ekonomi adalah kenaikan jangka panjang dalam kemampuan suatu negara untuk menyediakan semakin banyak jenis barang-barang ekonomi kepada penduduknya, kemampuan ini tumbuh sesuai dengan kemajuan teknologi dan penyesuaian kelembagaan serta ideologis yang diperlukannya.

Teori pertumbuhan ekonomi dapat didefinisikan sebagai penjelasan mengenai faktor-faktor apa yang menentukan kenaikan output perkapita dalam jangka panjang, dan penjelasan mengenai bagaimana faktor-faktor tersebut sehingga terjadi proses proses pertumbuhan (Boediono, 1999). Output per kapita adalah output total dibagi dengan jumlah penduduk (Sri Aditya, 2010).

Pertumbuhan ekonomi adalah kenaikan kapasitas dalam jangka panjang dari negara yang bersangkutan untuk menyediakan berbagai barang ekonomi kepada penduduknya yang ditentukan oleh adanya kemajuan atau penyesuaianpenyesuaian teknologi, institusional (kelembagaan), dan ideologis terhadap berbagai tuntutan keadaan yang ada (Simon Kuznetz dalam Todaro, 2004).

Menurut Nafziger (Sri Aditya, 2010), pertumbuhan ekonomi berkaitan dengan kenaikan produksi suatu negara atau kenaikan pendapatan per kapita suatu negara, sedangkan menurut Kuznets (Todaro, 2003), pertumbuhan ekonomi adalah kenaikan kapasitas dalam jangka panjang dari negara yang bersangkutan untuk menyediakan berbagai barang ekonomi kepada penduduknya. Kenaikan kapasitas itu sendiri ditentukan atau dimungkinkan oleh adanya kemajuan atau penyesuaian-penyesuaian teknologi, institusional (kelembagaan), dan ideologis terhadap berbagai tuntutan keadaan yang ada. Menurut Todaro (2003), ada tiga faktor utama dalam pertumbuhan ekonomi, yaitu :

1. Akumulasi Modal termasuk semua investasi baru yang berwujud tanah (lahan), peralatan fiskal, dan sumber 
daya manusia (human resources). Akumulasi modal akan terjadi jika ada sebagian dari pendapatan sekarang di tabung yang kemudian diinvestasikan kembali dengan tujuan untuk memperbesar output di masa-masa mendatang. Investasi juga harus disertai dengan investasi infrastruktur, yakni berupa jalan, listrik, air bersih, fasilitas sanitasi, fasilitas komunikasi, demi menunjang aktivitas ekonomi produktif. Investasi dalam pembinaan sumber daya manusia bermuara pada peningkatan kualitas modal manusia, yang pada akhirnya dapat berdampak positif terhadap angka produksi.

2. Pertumbuhan penduduk dan angkatan kerja. Pertumbuhan penduduk dan halhal yang berhubungan dengan kenaikan jumlah angka kerja (labor force) secara tradisional telah dianggap sebagai faktor yang positif dalam merangsang pertumbuhan ekonomi. Artinya, semakin banyak angkatan kerja semakin produktif tenaga kerja, sedangkan semakin banyak penduduk akan meningkatkan potensi pasar domestiknya.

3. Kemajuan Teknologi. Kemajuan teknologi disebabkan oleh teknologi cara-cara baru dan cara-cara lama yang diperbaiki dalam melakukanpekerjaan-pekerjaan tradisional. Ada 3 klasifikasi kemajuan teknologi, yakni :

a. Kemajuan teknologi yang bersifat netral, terjadi jika tingkat output yang dicapai lebih tinggi pada kuantitas dan kombinasi-kombinasi input yang sama.

b. Kemajuan teknologi yang bersifat hemat tenaga kerja (labor saving) atau hemat modal (capital saving), yaitu tingkat output yang lebih tinggi bisa dicapai dengan jumlah tenaga kerja atau input modal yang sama

c. Kemajuan teknologi yang meningkatkan modal, terjadi jika penggunaan teknologi tersebut memungkinkan kita memanfaatkan barang modal yang ada secara lebih produktif. Menurut Nugraheni, pengukuran akan kemajuan sebuah perekonomian memerlukan alat ukur yang tepat, beberapa alat pengukur pertumbuhan ekonomi antara lain yaitu :

Produk Domestik Bruto (PDB)

Produk Domestik Bruto (PDB), atau di tingkat regional disebut Produk Domestik Regional Bruto (PDRB), merupakan jumlah barang dan jasa akhir yang dihasilkan oleh suatu perekonomian dalam satu tahun dan dinyatakan dalam harga pasar. Baik PDB atau PDRB merupakan ukuran yang global sifatnya, dan bukan merupakan alat ukur pertumbuhan ekonomi yang tepat, karena belum dapat mencerminkan kesejahteraan penduduk yang sesungguhnya, padahal sesungguhnya kesejahteraan harus dinikmati oleh setiap penduduk di negara atau daerah yang bersangkutan.

Produk Domestik Bruto Per kapita/Pendapatan Per kapita

Produk domestik bruto per kapita atau produk domestik regional bruto perkapita pada skala daerah dapat digunakan sebagai pengukur pertumbuhan ekonomi yang lebih baik karena lebih tepat mencerminkan kesejahteraan penduduk suatu negara dari pada nilai PDB atau PDRB saja. Produk domestic bruto per kapita baik di tingkat nasional maupun di daerah adalah jumlah PDB nasional atau PRDB suatu daerah dibagi dengan jumlah penduduk di negara maupun di daerah yang bersangkutan, atau dapat disebut juga sebagai PDB atau PDRB rata-rata. 


\section{Upah Minimum}

Penetapan upah minimum sering menjadi masalah antara pengusaha dan pekerja. Di satu sisi penetapan upah minimum yang terlalu tinggi, tentunya akan memberatkan pengusaha. Selain itu pengusaha akan berhati-hati dalam memilih tenaga kerja yang digunakan. Tenaga kerja dipilih yang benar-benar produktif dan efisien. Sebagai akibatnya upah minimum akan mengakibatkan pengangguran dan hanya melindungi mereka yang sudah bekerja.

Di sisi lain kesejahteraan para buruh harus diperhatikan. Karena sebagian besar penduduk negara adalah para buruh. Upah minimum juga merupakan sumber perdebatan politik pendukung upah minimum yang lebih tinggi memandang sebagai sarana meningkatkan pendapatan. Sebaliknya para penentang upah minimum yang lebih tinggi mengklaim bahwa itu bukan cara yang terbaik. Kenaikan upah minimum berpotensi meningkatkan pengangguran (Mankiw, 2000:158).

\section{Fungsi upah secara umum, terdiri dari :}

a. Untuk mengalokasikan secara efisien kerja manusia, menggunakan sumber daya tenaga manusia secara efisien, untuk mendorong stabilitas dan pertumbuhan ekonomi.

b. Untuk mengalokasikan secara efisien sumber daya manusia. Sistem pengupahan (kompensasi) adalah menarik dan menggerakkan tenagakerja ke arah produktif, mendorong tenaga kerja pekerjaan produktif ke pekerjaan yang lebih produktif.

c. Untuk menggunakan sumber tenaga manusia secara efisien. Pembayaran upah (kompensasi) yang relatif tinggi adalah mendorong manajemen memanfaatkan tenaga kerja secara ekonomis dan efisien. Dengan cara demikian pengusaha dapat memperoleh keuntungan dari pemakaian tenaga kerja. Tenaga kerja mendapat upah (kompensasi) sesuai dengan keperluan hidupnya.

d. Mendorong stabilitas dan pertumbuhan ekonomi. Akibat alokasi pemakaian tenaga kerja secara efisien, sistem pengupahan (kompensasi) diharapkan dapat merangsang, mempertahankan stabilitas, dan pertumbuhan ekonomi.

Upah minimum adalah suatu penerimaan bulanan (terendah) sebagai imbalan dari pengusaha kepada karyawan untuk suatu pekerjaan atas jasa yang telah atau akan dilakukan dan dinyatakan atau dinilai dalam uang yang ditetapkan atas dasar suatu persetujuan atau peraturan perundangundangan serta dibayarkan atas dasar suatu perjanjian kerja antara pengusaha dengan karyawan termasuk tunjangan, baik karyawan itu sendiri maupun untuk keluarganya. Sebagaimana yang telah diatur dalam PP No. 8/1981 upah minimum ditetapkan secara minimum regional, sektor regional maupun sub sektoral, meskipun saat ini baru upah minimum regional yang dimiliki oleh setiap daerah.

Menurut Hasanuddin Rachman (2005), Tujuan penetapan upah minimum dapat dibedakan secara mikro dan makro. Secara mikro tujuan penetapan upah minimum yaitu

1. sebagai jaring pengaman agar upah tidak merosot.

2. mengurangi kesenjangan antara upah terendah dan tertinggi di perusahaan.

3. meningkatkan penghasilan pekerja pada tingkat paling bawah.

Sedangkan secara Makro,penetapan upah minimum bertujuan untuk : 
a. pemerataan pendapatan

b. peningkatan daya beli pekerja dan perluasan kesempatan kerja

c. perubahan struktur biaya industri sektoral

d. peningkatan produktivitas kerja nasional dan peningkatan etos dan disiplin kerja

e. memperlancar komunikasi pekerja dan pengusaha dalam rangka hubungan bipartite.

Upah minimum dapat dibedakan menjadi Upah Minimum Regional dan Upah Minimum Sektoral

1. Upah Minimum Regional Upah Minimum Regional adalah upah bulanan terendah yang terdiri dari upah pokok dan tunjangan tetap bagi seorang pekerja tingkat paling bawah dan bermasa kerja kurang dari satu tahun yang berlaku di suatu daerah tertentu. Berdasarkan Peraturan Menteri Tenaga Kerja : PER01/MEN/1999 tentang upah minimum, Upah Minimum Regional (UMR) dibedakan menjadi dua yaitu Upah Minimum Regional Tingkat I (UMR tk.I) dan Upah Minimum Reginal Tingkat II (UMR tk.II). Namun sesuai dengan Kepetusan Menteri Tenaga Kerja dan Transmigrasi (KEP-226/MEN/2000) tentang perubahan pada pasal 1,3,4,8,11,20 dan 21 PER-01/MEN/1999 tentang upah minimum, maka istilah Upah Minimum Regional Tingkat I (UMR tk.I) diubah menjadi Upah Minimum Provinsi (UMP) dan Upah Minimum Tingakat II (UMR tk.II) diubah menjadi Upah Minimum Kabupaten/Kota (UM kab/kota).

2. Upah Minimum Sektoral Upah minimum sektoral adalah upah yang berlaku dalam suatu provinsi berdasarkan kemampuan sektor. Berdasarkan Peraturan Menteri Tenaga Kerja : Per-01/MEN/1999 tentang upah minimum, upah minimum sektoral dibedakan menjadi Upah Minimum
Sektoral Regional Tingkat I (UMSR Tk. I) dan Upah Minimum Sektoral Regional Tingkat I I (UMSR Tk. II). Dalam perkembangan selanjutnya sesuai dengan Keputusan Menteri Tenaga Kerja dan Transmigrasi (KEP-226/MEN/2000) tentang perubahan pada pasal 1, 3, 4, 8, 11, 20 dan 21 PER-01/MEN/1999 tentang upah minimum, maka terjadi perubahan istilah Upah Minimum Sektoral Regional Tingkat I (UMSR Tk. I) menjadi Upah Minimum Sektoral Provinsi (UMSP) dan Upah Minimum Sektoral Regional Tingkat II (UMSR Tk. II) diubah menjadi UpahMinimum Sektoral Kabupaten /Kota (UMS kab/kota). Variabel-variabel yang mempengaruhi upah minimum regional (UMR) Tingkat I dan II sesuai dengan Peraturan Menteri Tenaga Kerja Nomor :Per-01/Men/1999, adalah sebagai beriku : kebutuhan hidup minimum (KHM), indeks harga konsumen (IHK), kemampuan, perkembangan dan kelangsungan perusahaan, tingkat upah pada umumnya yang berlaku di daerah tertentu dan antar daerah, kondisi pasar kerja, dan tingkat perkembangan perekonomian danpendapatan per kapita.

Peraturan Menteri Tenaga Kerja Nomor : Per-17/Men/VIII/2006 tentang Komponen dan Pelaksanaan Tahapan Pencapaian Kebutuhan Hidup Layak serta sesuai UU Nomor 13 Tahun 2003 Pasal 88 (4) tentang Ketenagakerjaan menyebutkan bahwa besaran upah minimum antara lain didasarkan pada tahap pencapaian KHL, pertumbuhan PDRB, produktivitas, dan mempertimbangkan keberadaan sektor marjinal (usaha yang paling tidak mampu). Pada pelaksanaannya, pertimbangan pada usaha tidak mampu ternyata belum dapat di operasionalkan.

Dalam hal ini upah minimum adalah terdiri dari upah pokok dan tunjangan tetap. Teori upah efisiensi (efficiency- 
wage) menyatakan upah yang tinggi membuat pekerja lebih produktif. Jadi, meskipun pengurangan upah akan menurunkan tagihan upah perusahaan, itu juga akan menurunkan produktivitas pekerja dan laba perusahaan.

\section{METODE PENELITIAN}

\section{A. Waktu dan Lokasi Penelitian}

Lokasi penelitian ialah kantor Bappeda Pemkab. Luwu Timur Jl. Soekarno Hatta. Karena Kantor Bappeda merupakan salah satu tempat yang berkaitan erat dengan penelitian selain BPS. Sedangkan waktu penelitian yaitu pada bulan April s.d. Mei 2016

\section{B. Jenis dan Sumber Data}

Dilihat dari pendekatan penelitian, penelitian ini menggunakan pendekatan kuantitatif. Pendekatan kuantitatif pada dasarnya menekankan analisisnya pada datadata numerikal (angka) yang diolah dengan metode statistika. Dengan metode kuantitatif akan diperoleh signifikasi perbedaan kelompok atau signifikansi hubungan antarvariabel yang diteliti. Data dapat diklasifikasikan menjadi 2 yaitu data kualitatif dan data kuantitatif. Data kuantitatif ini berupa data runtut waktu (time series) yaitu data yang disusun menurut waktu pada suatu variabel tertentu

\section{Metode Pengumpulan Data}

Metode pengumpulan data sangat penting digunakan dalam sebuah penelitian. Menurut Sugiyono $(2011 ; 30)$ pengumpulan data dapat dilakukan dalam berbagai setting, berbagai sumber, dan berbagai acara. Apabila dilihat dari berbagai sumber, maka pengumpulan data dapat menggunakan sumber primer dan sumber sekunder. Sumber primer adalah sumber data yang langsung memberikan data kepada pengumpul data, dan sumber sekunder merupakan sumber yang tidak langsung memberikan data kepada pengumpul data, misalnya melalui orang lain atau melalui dokumentasi. Metode yang dipakai dalam pengumpulan data adalah merupakan data sekunder yang didapatkan melalui dokumentasi dari Kantor BAPPEDA, kepustakaan dan internet research.

1. Kepustakaan merupakan teknik untuk mendapatkan informasi melalui catatan, literatur, dokumentasi dan lain-lain yang masih relevan dalam penelitian ini. Data yang digunakan dalam penelitian ini adalah data sekunder yang diperoleh dalam bentuk sudah jadi dari Bappeda Pemkab. Luwu Timur serta Badan Pusat Statistik (BPS) Kabupaten Luwu Timur. Data yang diperoleh adalah data dalam bentuk tahunan untuk masing-masing variabel.

2. Internet Research ialah dengan mencari melalui teknologi internet guna mengantisipasi ketertinggalan ilmu terus menerus mengalami perkembangan saat ini.

\section{Metode Analisis Data}

Metode analisis yang digunakan pada penelitian ini adalah dengan metode analisis regresi linier berganda. Regresi Linier Berganda adalah regresi linier dimana sebuah variabel terikat dihubungkan dengan dua atau lebih variabel bebas. Secara Umum bentuk persamaan regresinya adalah (dengan dua variabel) dalam menganalisis faktorfaktor yang mempengaruhi pendapatan perkapita di Kabupaten Luwu Timur, digunakan model berikut :

$$
\mathrm{Y}=\mathrm{a}+\mathrm{b} 1 \mathrm{X} 1+\mathrm{b} 2 \mathrm{X} 2+\mathrm{e}
$$

Keterangan :

$\mathrm{Y}$ : pendapatan perkapita

$\mathrm{a}=$ konstanta 
X1 : Pertumbuhan Ekonomi

X2 : Upah Minimum

b1 : Koefisien Pertumbuhan Ekonomi

b2 : Koefisien Upah Minimum

e : Error

Untuk mengetahui derajat tingkat pendapatan perkapita terhadap faktor - factor yang mempengaruhinya, digunakan konsep elastisitas. Besarnya nilai elastisitas dalam model ini dapat diketahui langsung besarnya nilai koefisien regresi variabel-variabel penduganya ( Gujarati, 2007:35).

Sebelum melakukan interpretasi terhadap hasil regresi dari model yang digunakan, terlebih dahulu dilakukan pengujian terhadap asumsi-asumsi klasik model OLS, sehingga model tersebut layak digunakan. Tujuannya agar diperoleh penaksiran yang bersifat Best Linier Unbiased Estimator (BLUE). Pengujian ini dimaksudkan untuk mendeteksi ada tidaknya multikolinearitas, heterokedastisitas dan autokolerasi pada hasil estimasi.

\section{Uji Asumsi Klasik}

Pengujian terhadap asumsi klasik bertujuan untuk mengetahui apakah model regresi tersebut baik atau tidak jika digunakan untuk melakukan penaksiran. Suatu model dikatakan baik apabila bersifat BLUE (Best Linear Unbiased Estimator), yaitu memenuhi asumsi klasik atau terhindar dari masalah-masalah multikolinearitas, heteroskedasitas, autokorelasi dan berdistribusi normal.

Untuk mendapatkan hasil yang memenuhi sifat tersebut perlu dilakukan pengujian asumsi klasik yang meliputi : uji multikolinearitas, uji heterokedastisitas, uji autokolerasi dan uji normalitas.

\section{a. Uji Multikolinearitas}

Pada mulanya multikolinearitas berarti adanya hubungan linear (korelasi) yang sempurna atau pasti, di antara beberapa atau semua variabel yang menjelaskan dari model regresi. Istilah multikolinearitas berkenaan dengan terdapatnya lebih dari satu hubungan linear pasti dan istilah kolinearitas berkenaan dengan terdapatnya satu hubungan linear. Pembedaan ini jarang diperhatikan dalam praktek, dan multikolinearitas berkenaan dengan kedua kasus tadi. Multikolineritas dalam penelitian ini dideteksi dengan menggunakan Auxilliary Regression yaitu dengan membandingkan besar nilai $\mathrm{R}^{2}$ model utama dengan $\mathrm{R}^{2}$ variabel - variabel independennya secara partial. Jika $\mathrm{R}^{2}$ model utama lebih besar daripada $\mathrm{R}^{2}$ variabelvariabel independennya maka tidak terjadi multikolinearitas (Gujarati, 1995).

\section{b. Uji Autokorelasi}

Autokorelasi adalah suatu keadaan dimana kesalahan penggangguan dari periode tertentu $(\mu \mathrm{t})$ berkorelasi dengan kesalahan pengganggu dari periode sebelumnya ( $\mu \mathrm{t}-1)$. Pada kondisi ini kesalahan pengganggu tidak bebas tetapi satu sama lain saling berhubungan.nmendeteksi ada atau tidaknya autokorelasi dapat menggunakan Uji Langrange Multiplier (LM Test). Dalam uji ini apabila nilai probabilitas dari $\mathrm{R}^{2}$ tidak signifikan $(<0,05)$, maka dapat disimpulkan autokorelasi (Insukindro, 2004).

\section{c. Uji Heterokedasitas}

Uji heterokedastisitas bertujuan untuk menguji apakah dalam model regresi terjadi ketidaksamaan varian dari residual suatu pengamatan ke pengamatan yang lain. Heterokedastisitas terjadi apabila variabel gangguan tidak mempunyai varian yang sama untuk semua observasi. Akibat adanya heterokedastisitas, penaksir OLS tidak bias tetapi tidak efisien. Cara untuk mendeteksi ada tidaknya heterokedastisitas dapat dilakukan dengan menggunakan white heteroscedasticity consistent standarderrors and covariance yang tersedia dalam program 
Eviews 7.0. Uji ini diterapkan pada hasil regresi dengan menggunakan prosedur equations dan metode OLS untuk masingmasing perilaku dalam persamaan simultan. Hasil yang perlu diperhatikan dari uji ini adalah nilai $\mathrm{F}$ dan $O b s^{*}$ Rsquared, secara khusus adalah nilai probability dari Obs*Rsquared. Dengan uji White, dibandingkan Obs*Rsquared dengan c(chisquared)tabel. Jika nilai Obs*Rsquared lebih kecil dari pada c tabel maka tidak ada heterokesdasitas pada model (Gujarati, 1995).

\section{d. Uji Normalitas}

Deteksi normalitas bertujuan untuk menguji apakah dalam model regresi,variabel pengganggu memiliki distribusi normal atau tidak. Dalam penelitian ini, untuk menguji apakah distribusi data normal atau tidak digunakan uji Jaque-Bera atau J-B Test membandingkan antara nilai J-B ( $\chi^{2}$ hitung) terhadap $\chi^{2}$ tabel (Chi-Square). Rumus yang digunakan (Insukindro, 2004) adalah:

$$
\mathrm{JB}=(\mathrm{N}-\mathrm{k}) / 6 \cdot[\mathrm{S} 2+(\mathrm{K}-3) 2]
$$

\section{HASIL DAN PEMBAHASAN}

\section{Gambaran Umum Wilayah Penelitian}

Kabupaten Luwu Timur secara geografis terletak pada koordinat $2^{\circ} 15^{\prime} 00^{\prime \prime}$ $3^{0}$ Lintang Selatan dan $120^{\circ} 30^{\prime}$ 00" sampai $121^{\circ} 30^{\prime}$ 00" bujur Timur. Kabupaten ini berasal dari pemekaran Kabupaten Luwu Utara yang disahkan dengan UU Nomor 7 Tahun 2003 pada tanggal 25 Februari 2003. Malili adalah ibu kota dari Kabupaten Luwu Timur yang terletak di ujung utara Teluk Bone. Kabupaten ini memiliki luas wilayah $6.944,98 \mathrm{~km}^{2}$. Kabupaten ini terdiri atas 11 Kecamatan yakni Kecamatan Malili (14 Desa dan 1 Kelurahan), kecamatan Angkona (10 Desa), Tomoni (12 Desa dan 1 Kelurahan), Tomoni Timur (8 Desa), Kalaena (7 Desa), Towuti (18 Desa), Nuha (4 Desa dan 1 Kelurahan), Wasponda (6 Desa), Wotu (16
Desa), Burau (18 Desa) dan Mangkutana (11 Desa). Di kabupaten ini terletak Sorowako, tambang nikel yang dikelola oleh INCO, sebuah perusahaan Kanada yang kini berubah nama menjadi PT Vale. Pendapatan per kapita masyarakat Luwu Timur pada tahun 2014 adalah Rp. 75,58 juta.

Diketahui setiap tahun jumlah penduduk di wilayah Kab. Luwu Timur terus meningkat. Pada tahun 2010 adalah sebesar 258.573 jiwa, 2011 sebesar 266.532 jiwa, 2012 sebesar 269.734 jiwa, 2013 sebesar 275.523 jiwa, dan pada tahun 2014 jumlah penduduk Kab. Luwu Timur Sebesar 277.488 jiwa dan tercatat kepadatan penduduk Kab. Luwu Timur sebesar 40 jiwa per $\mathrm{km}^{2}$.

\section{Deskripsi Variabel Penelitian}

Pendapatan perkapita (Y)

Definisi pendapatan perkapita merupakan indicator yang dapat digunakan untuk mengukur keberhasilan pembangunan ekonomi. Dalam penelitian ini pendapatan perkapita Kabupaten Luwu Timur yang di gunakan adalah Pendapatan perkapita atas dasar harga konstan dan berdasar harga berlakunya. Yang direalisasikan dalam bentuk table berikut.

Tabel 4.1.

Pendapatan perkapita Kabupaten Luwu Timur tahun 2010-2014

\begin{tabular}{|c|c|}
\hline Tahun & $\begin{array}{c}\text { Pendapatan perkapita (juta } \\
\text { rupiah) }\end{array}$ \\
\hline 2010 & $48.538 .668,38$ \\
\hline 2011 & $45.265 .987,54$ \\
\hline 2012 & $46.604 .218,56$ \\
\hline 2013 & $48.353 .630,63$ \\
\hline 2014 & $51.203 .153,62$ \\
\hline
\end{tabular}


Dari table 4.1 terlihat fluktuatif yakni dari 48,54 Trilyun pada tahun 2010 mengalami penurunan sekitar 3,27 miliyar atau sekitar (4,29\%) pada tahun 2011. Sedangkan pada tahun 2012 nilai pendapatan perkapita mulai bangkit kembali dengan nilai 46,60 trilyun dan terus meningkat dengan nilai 48,35 trilyun pada tahun 2013. Kinerja yang baik terus bertahan hingga pada tahun 2014 nilai pendapatan perkapita mencapai 13,79 trilyun dan hal ini meningkat dengan selisih 2,85 trilyun dari tahun sebelimnya.

Fluktuasi pendapatan perkapita ini terjadi terutama dipengaruhi oleh naik turunnya harga nikel di pasar dunia dan produksi nikel dari PT.Vale Indonesia Tbk., yang merupakan perusahaan pertambangan nikel yang beroprasi di Luwu Timur.

Jika dilihat perkategori, yang menjadi kategori pemberi kontribusi tertinggi bagi pembentukan pendapatan perkapita di Kabupaten Luwu Timur dari 2010-2014 adalah kategori pertambangan dan penggalian. Yang mana, nilai kategori ini didomonasi subkategori pertambangan bijih logam (Nikel). Sedangkan kategori yang member kontri busi terkecil dari 2010-2014 adalah dari kategori pengadaan air,pengolahan sampah, Limbah dan Daur Ulang. Pada tahun 2014 kategori ini hanya mampuh menyumbang sebesar 0,96 Miliyar rupiah.

Pertumbuhan Ekonomi $\left(\mathrm{X}_{1}\right)$ Kabupaten Luwu Timur

Pertumbuhan ekonomi merupakan indicator kesejahteraan penduduk suatu wilayah , semakin tinggi pertumbuhan ekonomi maka sektor riil di dalam wilayah tersebut juga mengalami peningkatan.

Pertumbuhan ekonomi Kabupaten Luwu Timur mencapai 2 digit angka. Angka 13,19 persen merupakan pertumbuhan tertinggi di Sulawesi Selatan dalam kurun waktu 5
tahun.Hal ini terjadi karena produksi nikel yang meningkat signifikan. Namun pada tahun-tahun berikutnya mengalami penurunan dikarenakan berkurangnya produksi nikel yang di sebabkan oleh berbagai factor, sekalipun produktivitas nikel tertutupi oleh meningkatnya pertumbuhan pada kategori lainnya, masih terlihat dampaknya yang turun hingga negative 4,29\%. Hal ini dapat dilihat dari table berikut.

Tabel 4.2

Data pertumbuhan ekonomi Kabupaten Luwu Timur tahun 2010-2014

\begin{tabular}{|c|c|}
\hline Tahun & $\begin{array}{c}\text { Pertumbuhan Ekonomi } \\
\text { (persen) }\end{array}$ \\
\hline 2010 & 13,19 \\
\hline 2011 & $-4,29$ \\
\hline 2012 & 5,62 \\
\hline 2013 & 6,31 \\
\hline 2014 & 8,47 \\
\hline
\end{tabular}

Dari table 4.2 memperlihatkan bahwa pada tahun 2010 pertumbuhan ekonomi Kabupaten Luwu Timur mencapai 2 digit angka yaitu 13,19 persen sedangkan pada tahun 2011 mengalami penurunan hingga negative 4,29 persen. Hal ini terjadi karena pengaruh dari adanya gangguan produksi Nikel yang di sebabkan oleh gempabumi dan kecelakaan pada tanur sehingga produksi nikel berkurang. Namun pada tahun berikutnya terus mengalami peningkatan yang berdampak pada membaiknya pertumbuhan ekonomi. selain itu meskipun produktivitas nikel menurun, dapat tertutupi oleh peningkatan pertumbuhan kategori lainnya.

Upah Minimum $\left(\mathrm{X}_{2}\right)$

Definisi upah minimum Menurut Undang-Undang No. 13 Tahun 2014 adalah hak pekerja/buruh yang dinyatakan dalam 
bentuk uang sebagai imbalan dari pengusaha atau pemberi kerja kepada pekerja/buruh yang di tetaapkan dan di bayarkan menurut perjanjian kerja, kesepakatan, atau peraturan perundang-undangan termasuk tunjangan pada pekerja/buruh dan keluarganya atas suatu pekerjaan adan atau jasa yang telah atau akan dilakukan. Upaha minimum Kabupaten Luwu Timur dari tahun ketahun juga mengalami peningkatan dari Rp. 1.050.000,- pada tahun 2010 hingga mencapai Rp. 1.890.000,- pada tahun 2014. Hal ini dapat dilihat dari table berikut:

Tabel 4.3

Upah Minimum Kabupaten Luwu Timur tahun 2010-2014

\begin{tabular}{|c|c|}
\hline Tahun & Upah minimum (rupiah) \\
\hline 2010 & 1.050 .000 \\
\hline 2011 & 1.155 .000 \\
\hline 2012 & 1.260 .000 \\
\hline 2013 & 1.483 .000 \\
\hline 2014 & 1.890 .000 \\
\hline
\end{tabular}

Dari ketiga data yang telah ada dapat pula ditampilkan dalam tabel data dari perekonomian Kabupaten Luwu Timur dari tahun 2010-2014 sebagai berikut.

Tabel 4.4

\begin{tabular}{|c|c|c|c|}
\hline Tahun & Y & X1 & X2 \\
\hline $\mathbf{2 0 1 0}$ & $48.538 .668,38$ & 13,19 & 1.050 .000 \\
\hline $\mathbf{2 0 1 1}$ & $45.265 .987,54$ & $-4,29$ & 1.155 .000 \\
\hline $\mathbf{2 0 1 2}$ & $46.604 .218,56$ & 5,62 & 1.260 .000 \\
\hline $\mathbf{2 0 1 3}$ & $48.353 .630,63$ & 6,31 & \\
\hline $\mathbf{2 0 1 4}$ & $51.203 .153,62$ & 8,47 & 1.483 .000 \\
\hline
\end{tabular}

Sumber: BAPPEDA Kab. Luwu Timur 20102014

\section{Hasil Uji Statistik Deskriptif}

Statistik deskriptif adalah statistik yang mempunyai tugas untuk mengumpulkan data, mengolah data dan kemudian menyajikan dalam bentuk yang baik. Beberapa hal yang termasuk kedalam bagian ini adalah mengumpulkan data mengolah data menganalisis data dan menyajikannya (Djarwanto, 2001:2)

Dari hasil pengumpulan data sekunder mengenai pertumbuhan ekonomi, upah minimum dan pendapatan perkapita Kabupaten Luwu Timur Tahun 2010-2014, maka statistic deskriptif yaitu minimum, maksimum, mean, dan standar deviasi adalah sebagai berikut: 
Tabel 4.5. Statistik Deskriptif

Descriptive Statistics

\begin{tabular}{|c|c|c|c|c|c|c|c|}
\hline & $\mathrm{N}$ & Minimum & Maximu & \multicolumn{2}{|c|}{ Mean } & \multirow{2}{*}{$\begin{array}{c}\text { Std. } \\
\text { Deviatio } \\
\mathrm{n} \\
\text { Statistic }\end{array}$} & \multirow{2}{*}{$\begin{array}{l}\text { Variance } \\
\text { Statistic }\end{array}$} \\
\hline & Statistic & Statistic & Statistic & Statistic & Std. Error & & \\
\hline $\begin{array}{l}\text { pendapatan } \\
\text { perkapita }\end{array}$ & 5 & $\begin{array}{r}1132659 \\
1,20\end{array}$ & $\begin{array}{r}1379438 \\
5,60\end{array}$ & $\begin{array}{l}123271 \\
96,4800\end{array}$ & $\begin{array}{r}429056,6 \\
0457\end{array}$ & $\begin{array}{r}959399 \\
73402\end{array}$ & $\begin{array}{r}9204478 \\
49644,04 \\
7\end{array}$ \\
\hline $\begin{array}{c}\text { pertumbuhan } \\
\text { ekonomi }\end{array}$ & 5 & $-4,29$ & 13,19 & 5,8600 & 2,86202 & 6,39968 & 40,956 \\
\hline $\begin{array}{c}\text { upah } \\
\text { minimum }\end{array}$ & 5 & $\begin{array}{r}1050000 \\
00\end{array}$ & $\begin{array}{r}1890000, \\
00\end{array}$ & $\begin{array}{r}136760 \\
0,0000\end{array}$ & $\begin{array}{r}148974,0 \\
2458\end{array}$ & $\begin{array}{r}333116 \\
04585\end{array}$ & $\begin{array}{r}1109663 \\
00000,00 \\
0\end{array}$ \\
\hline $\begin{array}{l}\text { Valid N } \\
\text { (listwise) }\end{array}$ & 5 & & & & & & \\
\hline
\end{tabular}

Berdasarkan table di atas, dapat di jelaskan kondisi perekonomian sebagai berikut :

a. Pertubuhan ekonomi dengan nilai minimum sebesar $-4,29 \%$ yang menunjukkan perumbuhan ekonomi terendah terjadipada tahun 2011

b. Pertumbuhan ekonomi Kabupaten Luwu Timur dengannilai maksimum yaitu sebesar 13.19\%, hasil menunjukkan bahwa pertumbuhan ekonomi trtinggi terjadi padatahun 2010 .

c. Upah minimum dengan nilai minimum terjadi pada tahun 2010 sebesar Rp 1.050.000,- menunjukkan bahwa upah minimum terendah terjadi pada tahun 2010

d. Upah minimum dengan nilai maksimum sebesar Rp 1.890.000,- menunjukkan bahwa Upah minimum tertinggi adalah pada tahu 2014.

e. Pendapatan perkapita dengan nilai minimum 11,32 Trilyun, hasil menunjukkan

bahwa

pendapatan perkapita terendah Kabupaten luwu timur terjadi pada tahun 2011

f. Pendapatan perkapita dengan nilai maksimum 13,79 Trilyun rupiah, hasil menunjukkan bahwa pendapatan perkapita tertinggi terjadi pada tahun 2014.

\section{Hasi Uji Regresi}

Dalam melakukan analisis pengaruh pertumbuhan ekonomi dan upah minimum terhadap pendapatan perkapita di Kabupaten Luwu Timur Tahun 20102014 dengan variable independennya adalah pertumbuhan ekonomi dan upah minimum, pemilihan model ini dilakukan dengan analisis linier berganda karna terdapat dua variable independen.

Berdasarkan hasil analisis dengan menggunakan program SPSS maka diperoleh hasil Analisis Regresi sebagai berikut.

Tabel 4.5 Persamaan Regresi 


\section{Coefficients $^{a}$}

\begin{tabular}{|c|c|c|c|c|c|c|}
\hline & \multirow[t]{2}{*}{ Model } & \multicolumn{2}{|c|}{$\begin{array}{c}\text { Unstandardized } \\
\text { Coefficients }\end{array}$} & \multirow{2}{*}{$\begin{array}{c}\begin{array}{c}\text { Standardized } \\
\text { Coefficients }\end{array} \\
\text { Beta }\end{array}$} & \multirow[t]{2}{*}{$\mathrm{T}$} & \multirow[t]{2}{*}{ Sig. } \\
\hline & & B & Std. Error & & & \\
\hline \multirow{3}{*}{1} & (Constant) & $\begin{array}{r}8481633,49 \\
0\end{array}$ & 150860,953 & & 56,222 & ,000 \\
\hline & $\begin{array}{l}\text { pertumbuhan } \\
\text { ekonomi }\end{array}$ & 44579,598 & 5658,583 & 297 & 7,878 & ,016 \\
\hline & upah minimum & 2,621 & 109 & ,910 & 24,109 & ,002 \\
\hline & & & & & & \\
\hline
\end{tabular}

a. Dependent Variable: pendapatan perkapita

upah minimum naik sebesar satu satuan, maka pendapatan perkapita

Hasil estimasi model dapat ditulis dalam persamaan berikut: $\mathrm{Y}=8481633,490+44579,598 \mathrm{X}_{1}+$

$$
2,621 X_{2}
$$

Dari persamaan diatas dapat dia artikan sebagai berikut :

a. Nilai konstanta sebesar 8481633,49 menyatakan bahwa jika tidak ada variable independen yang dianggap konstan $\left(\mathrm{X}_{1}=0\right.$ dan $\left.\mathrm{X}_{2}=0\right)$, maka pendapatan perkapita dikatakan meningkat sebesar 8481633,49.

b. Nilai koefisien regresi pertumbuhan ekonomi sebesar 44579,598, artinya apabila ada perubahan kenaikan pertumbuhan ekonomi sebesar satu satuan maka akan menaikkan pendapatan perkapita sebesar 44579,598 satuan dengan asumsi variable lainnya konstan

c. Nilai koefien regresi upah minimum sebesar 2,621, yang artinya apabila akan naik sebesar 2,621 satuan dengan asumsi variable lainnya konstan.

\section{Hasil Uji Hipotesis}

a. Hasil uji hipotesis signifikan ( Uji statistik T) Untuk menguji hipotesis secara parsial digunakan Uji t yaitu untuk menguji secara parsial variable independen terhadap variable dependennya hasil pengujian Uji $t$ sebagai berikut. 
Tabel 4.6 Uji T

\begin{tabular}{|c|c|c|c|c|c|c|}
\hline \multicolumn{7}{|c|}{ Coefficients ${ }^{a}$} \\
\hline & \multirow[t]{2}{*}{ Model } & \multicolumn{2}{|c|}{$\begin{array}{c}\text { Unstandardized } \\
\text { Coefficients }\end{array}$} & \multirow{2}{*}{$\begin{array}{c}\begin{array}{c}\text { Standardized } \\
\text { Coefficients }\end{array} \\
\text { Beta }\end{array}$} & \multirow[t]{2}{*}{$\mathrm{T}$} & \multirow[t]{2}{*}{ Sig. } \\
\hline & & B & Std. Error & & & \\
\hline & (Constant) & 8481633,49 & 150860,953 & & 56,222 & 000 \\
\hline 1 & $\begin{array}{c}\text { pertumbuhan } \\
\text { ekonomi }\end{array}$ & 44579,598 & 5658,583 & 297 & 7,878 & 016 \\
\hline & upah minimum & 2,621 & 109 & ,910 & 24,109 & ,002 \\
\hline
\end{tabular}

a. Dependent Variable: pendapatan perkapita

Hasil perhitungan statistic tersebut menunjukkan bahwa ada dua variable independen yang berpengaruh signifikan terhadap variable dependen. Berdasarkan table di atas dapat disimpulkan mengenai uji hipotesis secara parsial dari masing-masing variable inependen terhadap variable dependennya sebagai berikut:

Ha : diduga ada pengaruh signifikan dari pendapatan pertumbuhan ekonomi dan upah minimum terhadap pendapatan erkapita di Kabupaten Luwu Timur.

Pada output regresi menunjukkan bahwa angka signifikan pertumbuhan ekonomi sebagai $X_{1}$ sebesar 0,016, nilai ini lebih kecil dari tingkat signifikan0,05 $(0,016<0,05)$ dan di peroleh $t_{\text {hitung }}$ sebesar 7,878 lebih besar dari $t_{\text {tabel }} 2,571(7,878>2,571)$. Sehingga dapat di simpulkan bahwa pertumbuhan ekonomi berpengaruh secara signifikan terhadap pendapatan perkapita.

Pada output regresi menunjukkan bahwa angka signifikan untuk variable upah minimum sebagai $\mathrm{X}_{2}$ sebesar 0,002, nilai ini lebih kecil dari tingkat sinifikan $0 ., 05(0,002<0,05)$ dan $t_{\text {hitung }}$ sebesar 24,109 lebih besar dari tabel sebesar $2,571(24,109>2,571)$. Sehungga dapat disimpulkan bahwa upah minimum berpengaruh secara signifikan terhadap pendapatan perkapita.

b. Hasil Uji Signifikan (Uji Statistik F)

Uji F dilakukan untuk melihat apakah variable independen berpengaruh terhadap variable dependen. Dari dari pengujian simultan diperoleh hasil berikut: 
Tabel 4.7 Uji F

ANOVAa $^{\text {a }}$

\begin{tabular}{|c|c|c|c|c|c|c|}
\hline \multicolumn{2}{|c|}{ Model } & Sum of Squares & Df & Mean Square & $\mathrm{F}$ & Sig. \\
\hline & Regression & $\begin{array}{r}367153338446 \\
6,298\end{array}$ & 2 & $\begin{array}{r}183576669223 \\
3,149\end{array}$ & 357,919 &, $003^{\mathrm{b}}$ \\
\hline 1 & Residual & $\begin{array}{r}10258014109,8 \\
91\end{array}$ & 2 & $\begin{array}{r}5129007054,94 \\
5\end{array}$ & & \\
\hline & Total & $\begin{array}{r}368179139857 \\
6,189\end{array}$ & 4 & & & \\
\hline
\end{tabular}

a. Dependent Variable: pendapatan perkapita

b. Predictors: (Constant), upah minimum, pertumbuhan ekonomi

Ha : Ho ada pengaruh secara simultan dari pertumbuhan ekonomi dan upah minimum terhadap pendapatan perkapita di Kabupaten Luwu Timur.

Berdasar table diatas dapat disimpulkan mengenai uji hipotesis secara simultan dari variable independen terhadap variable dependen, secara simultan (Uji F) dari hasil perhitungan di dapatkan nilai $F_{\text {hitung }}$ sebesar 357,919 (sig. $F=0,003$ ). Karena nilai sig. $F<$ $5 \%(0,003<0,05)$, artinya bahwa variable independen berpengaruh signifikan terhadap variable dependen. Sehingga Ha menerima dan Ho ditolak.

c. Koefisien Determinasi

Tabel 4.8 Koefisien Determinasi Model Summary

\begin{tabular}{|c|c|c|c|c|}
\hline $\begin{array}{c}\text { Mode } \\
\mathrm{l}\end{array}$ & $\mathrm{R}$ & $\begin{array}{c}\mathrm{R} \\
\text { Squar } \\
\mathrm{e}\end{array}$ & $\begin{array}{c}\text { Adjuste } \\
\mathrm{d} \mathrm{R} \\
\text { Square }\end{array}$ & $\begin{array}{c}\text { Std. Error } \\
\text { of the } \\
\text { Estimate }\end{array}$ \\
\hline 1 & $\begin{array}{r}99 \\
\mathrm{a}\end{array}$ &, 997 &, 994 & $\begin{array}{r}71617,08 \\
633\end{array}$ \\
\hline
\end{tabular}

a. Predictors: (Constant), upah minimum, pertumbuhan ekonomi

Nilai koefisien determinasi $\mathrm{R}^{2}$ ini mencerminkan seberapa besar variasi dari variable dependen (Y) dapat di terangkan oleh variable independen (X). Bila nilai koefisien determinasi sama dengan $0\left(\mathrm{R}^{2}=0\right)$, artinya variasi dari Y tidak dapat di terangkan oleh X sma sekali. Sedangkan, jika $\mathrm{R}^{2}=1$ maka semua titik pengamatan berada tepat pada garis regresi.

Nilai Adjusted R-Square (Koefisien Determinasi) menunjukkannilai sebesar 0.997 atau 99,7\%. Menunjukkan bahwa kemampuan menjelaskan variable dependen (pendapatan perkapita) sebesar 99,7\%, sedangkan sisanya $0,3 \%$ dijelaskan oleh variable lain diluar variable independen (pertumbuhan ekonomi dan upah minimum) tersebut yang tidak di masukkan dalam model.

\section{PEMBAHASAN}

Pengaruh Pertumbuhan Ekonomi dan Upah Minimum Terhadap Pendapatan Perkapita di Kabupaten Luwu Timur Tahun 2010-2014 
Hipotesis pertama menyatakan bahwa Pertumbuhan ekonomi berpengaruh secara signifikan terhadap Pendapatan Perkapita. Dan dari hasil dari serangkaian uji hipotesi yang dilakukan hasilnya menunjukkan bahwa hipotesis awal adalah benar adanya bahwa pertumbuhan ekonomi berpengaruh signifikan terhadap pendapatan perkapita hal ini di buktikan berdasarkan hasil Uji $\mathrm{T}$ yang mana di peroleh nilai signifikan sebesar 0,016 lebih kecil dari tingkat signifikan $0,05 \quad(0,016<0,05)$ yang menunjukkan bahwa ada pengaruh dari pertumbuhan ekonomi terhadap pendapatan perkapita di Kabupaten Luwu Timur.

Hasil ini menunjukkan bahwa ada pengaruh signifikan antara pertumbuhan ekonomi yang mempengaruhi pendapatan perkapita di Kabupaten Luwu Timur. Dimana ketika terjadi kenaikan pada pertumbuhan ekonomi berarti tingkat pendapatan perkapita juga akan ikut meningkat.

Dari hasil penelitian ini menunjukkan bahwa tingkat pendapayan perkapita di Kabupaten Luwu Timur di pengaruhi oleh tingkat pertumbuhan ekonomi dalam artian bahwa jika pertumbuhan ekonomi di Kabupaten Luwu Timur meningkat sebesar 44579,598 satuan maka akan meningkatkan pendapatan perkapita sebesar satu satuan dengan syarat nilai variable lainnya konstan. Hal ini menunjukkan bahwa variable pertumbuhan ekonomi berpengaruh signifikan terhadap pendapatan perkapita di Kabupaten Luwu Timur.

1. Pengaruh Upah Minimum Terhadap Pendapatan Perkapita

Berdasarkan hasil analisis dapat di jelaskan bahwa variable upah minimum berpengaruh positif dan signifikan dengan nilai koefisien positif sebesar 2,621 terhadap pendapatan perkapita di Kabupaten Luwu Timur dalam kurun waktu 2010-2014.

Hal ini menunjukan bahwa secara langsung upah minimum memiliki hubungan positif dan berpengaruh signifikan terhadap pendapatan perkapita.

Semakin meningkat tingkat upah minimum akan semakin meningkatkan pendapatan masyarakat sehingga kesejahteraan juga meningkat. Dan hal ini juga akan seiring dengan meningkatnya pendapatan perkapita di wilayah Kabupaten Luwu Timur.

Dan berdasarkan hasil penelitian, ditemukan bahwa secara langsung Upah minimum berpengaruh positif dan signifikan terhadap pendapatan perkapita. Menurut penulis hal ini terjadi karena sektor terbesar yang mendukung perekonomian di Kabupaten Luwu Timur adalah pertambanagan dan penggalian, yang diikuti oleh sektor pertanian, perdaganagan dan sektor lainnya.

\section{KESIMPULAN}

Penelitian ini dimaksudkan untuk mengetahui pengaruh pertumbuhan ekonomi dan upah minimum terhadap perndapatan perkapita di Kabupaten Luwu Timur selama kurun waktu 2010-2014. Berdasarkan uraian hasil penelitian dan pembahasan maka dapat ditarik kesimpulan dari penelitian adalah:

Dari hasil regresi berganda menunjukkan bahwa kedua variabel bebas berpengaruh signifikan terhadap variabel terikat (pendapatan perkapita).

\section{Saran}

Dari hasil pengujian yang telah dilakukan ada beberapa saran yang dapat diberikan sebagai berikut:

Apabila melihat beberapa tahun terakhir ini kinerja ekonomi Pemerintah Kabupaten Luwu Timur terbukti baik, ini terlihat dari tingginya pertumbuhan ekonomi dan semakin meningkatnya Pendapatan Perkapita, tetapi hal itu seharusnya juga diimbangi dengan semakin tingginya tingkat 
kesejahteraan masayarakat. Karena itu pemerintah diharapkan mampu untuk dapat lebih memaksimalkan sektor yang menjadi keunggulan di Kabupaten Luwu Timur yaitu sektor industry.

Salah satu cara yang bisa dilakukan adalah dengan menambah jumlah investasi di sektor industry ini. Semakin besar investasi di sektor industry maka akan membuat sektor tersebut tumbuh. Sektor tersebut dikatakan tumbuh apabila produksi barang dan jasa meningkat dari tahun sebelumnya. Terjadinya pertumbuhan ekonomi yang baik maka akan

\section{DAFTAR PUSTAKA}

Arikunto, Suharsimi. 2006. Prosedur Penelitian: Suatu pendekatan Praktik. Jakarta : PT RINEKA CIPTA.

Boediono. 1981. Ekonomi Internasional Edisi 1. Yogyakarta. BPFE

BPS Kab. Luwu Timur. 2014. Perkembangan Perekonomian Kabupaten Luwu Timur 2010-2014. Malili: BPS Kab. Luwu Timur.

BPS Kab. Luwu Timur. 2015. Profil Kabupaten

Luwu Timur 2015. Malili: BPS Kab. Luwu Timur.

Gujarati, Damodar N. 2007. Dasar-Dasar Ekonometrika. Edisi Ketiga. Jilid 2. Jakarta: Erlangga.

Istiandari, Rahmasari. 2009. Tata Kelola Ekonomi Daerah dan Kesejahteraan Masyarakat di Indonesia. Jakarta: FEUI.

Jhingan, 1994. Ekonomi Pembangunan dan Perencanaan. Jakarta: Raja Grafindo.

Kristianto, Prabowo Dwi. 2014. Analisis Pengaruh Pertumbuhan Ekonomi, Upah Minimum, dan Pendapatan Perkapita meningkatkan pendapatan perkapita di Kabupaten Luwu Timur.

Upah minimum yang naik setiap tahunnya tentu akan memberatkan pengusaha, jika tidak diimbangi oleh produktivitas dari pegawai atau pun buruh. Sehingga pabrik akan mengurangi pegawai atau pun buruh agar dapat mengurangi beban biaya produksi. Karena itu pemerintah Kabupaten Luwu Timur diharapkan lebih mendukung program berwirausaha. Sehingga hal ini di harapkan mampuh meningkatkan taraf hidup masyarakat yang juga akan berdampak pada meningkatnya Pendapatan Perkapita Kab. Luwu Timur.

Terhadap Kemiskinan di Kabupaten Brebes. Semarang. Universitas Diponegoro

Mankiw, N.Gregory. (2000). Teori Makroekonomi, Edisi Keempat. Jakarta: Erlangga.

Oktavia, Putu. 2008. Analisis Makroekonomi. MET 08.05.

Sapar Dan Adi Riyanto Suprayitno. 2012. Pengantar Metode Penelitia. Bogor: Makaira Printing Plus.

STIEM Palopo. 2014. Buku Pedoman Penulisan Skripsi. Palopo: STIEM Palopo.

Sugiono. 2009. Metode Penelitian Pendidikan: Pendekatan Kuantita Kualita. Bandung: Alfabeta.

Sugiyono. 2011. Metode Penelitian Kuantitatif dan Kualitatif dan R\&D. Bandung: Alfabeta.

Sukirno, Sadono. 2004. Pengantar Teori Makroekonomi. Jakarta: Raja Grafindo Persada.

Syamsurijal, 2008. Pengaruh Tingkat Kesehatan Dan Pendidikan Terhadap 
Pertumbuhan Pendapatan Perkapita Di Sumatera Selatan. Jurnal Ekonomi Pembangunan. Vol. 6. No. 1. Juni 2008. Hal. 1-9. Ogan Ilir: FE-Universitas Sriwijaya

Todaro M.P. 2000. Pembangunan Ekonomi di Dunia Ketiga. Jakarta: Erlangga

Utama, Putra Fajar. 2010. Analisis Pertumbuhan Ekonomi Dan Tingkat Ketimpangan Di Kabupaten/Kota Yang Tergabung Dalam Kawasan Kedungsepur Tahun 2004-2008. Jurnal Ekonomi. Semarang: Universitas Diponegoro
Widiyati, Sri. 2011. Pengembangan Ekonomi Kabupaten Semarang Melalui Wilayah Andalan. Jurnal Ekonomi Pembangunan. Vol. 7 No.1 Maret 2011. Hal : 1- 5. POLINES Semarang.

Yudha, Pranata. 2012 Pengaruh pertumbuhan Ekonomi, Upah Minimum, Tingkat Pengangguran Terbuka, dan Inflasi terhadap Kemiskinan di Indonesia tahun 2009-2011. Jurnal Ekonomi. Semarang: Universitas Negeri Semarang 